Proc $2^{\text {nd }}$ APCRS

\title{
Coral reef condition on community based marine protected area in Eastern Indonesia
}

\author{
Maruf KASIM ${ }^{1,2, *}$ \\ ${ }^{1}$ Faculty of Fishery and Marine Science, Haluoleo University, Southeast Sulawesi, 93111 Indonesia \\ ${ }^{2}$ Team Leader Consultant, COREMAP Phase II PMU Buton District, Indonesia \\ * Corresponding author: M. Kasim \\ E-mail: marufkasim@hotmail.com
}

\begin{abstract}
The study was carried out in 39 Marine Proentire population, village regulations were formulated durtected Areas within the Province of Southeast Sulawesi, Eastern Indonesia. In particular, the research would look at community participation in creating marine protected area (MPA) to preserve healthy fisheries around coral reef locations. To clarify coral reef condition in the marine protected areas, survey and monitoring of coral reefs were conducted in all stations of this region. From 2007, local people in this region have started to create marine protected areas using community participation in their village. At the village level, MPAs were created through community participation. In 2007, my research on MPA in eastern Indonesia showed that $30.16 \%$ of live coral, $40 \%$ ing community workshop conducted in 2007, aimed to support effective implementation of marine protected areas. This process was facilitated by Coral Reef Rehabilitation and Management Program Phase II (COREMAP II) of the World Bank. Community marine protected areas provide the best protection for species of coral reef, fish and wildlife. This approach has created a method through which the capacity of local community is improved, as they can often serve as the best managers and supervisor to ensure the protection of these areas from overfishing, bombing and cyanides. This is one of the most successful strategies for marine conservation in Indonesia.
\end{abstract} of dead coral, $17.23 \%$ of other fauna, $10.46 \%$ of abiotic substances (sands and stones), and $2.15 \%$ of macro algae covered the entire coral reef observed region. While in 2008 , the of live coral increased to $33.3 \%$, dead coral decreased to $36 \%$, other fauna have reached $6.6 \%$, abiotic (sands and stones) have turned into $19.5 \%$ and macro algae increased to $4.9 \%$. These figures describe that within 1 year, community involvement through this program has successfully increased live coral by $3.14 \%$, decreased dead coral by $4 \%$, decreased other fauna by $10.6 \%$, increased abiotic substances (sands and stones) by $9 \%$ and increased macro algae by $2.8 \%$. Most of the coral fishes, particularly those of target fish group (economic fish) increased during 2007-2009. In order to optimize an understanding and pursuance of marine protected area to

Keywords coral reef, living coral, marine protected area, eastern Indonesia.

\section{Introduction}

Coral reefs are an important part of an ecosystem. They represent the skeletons of algae and corals solidified into calcium carbonate. In terms of the ecosystem, coral reefs support a huge amount of sea life by recycling nutrients in nutrient-low parts of the ocean, therefore providing life and health for the surrounding coastal and marine life. They also represent homes for various types of tropical 
fish, and other sea organisms, such as lobsters and sea turtles. Pollution and over fishing have developed a serious threat to the delicate balance in the coral reef ecosystems. Excessive fishing, most notably using cyanide, destroys the structure of the reef and the organisms associated with it.

There are two different ways in which humans have contributed to the degradation of the Earth's coral reefs, indirectly and directly. Indirectly, coral reefs can live only within a certain temperature and salinity range. Global warming caused by the green house effect has raised the temperature of the oceans causing corals to get sick and die. The most obvious sign of corals' sickness is bleaching. This occurs when the algae inside die or leave the coral. These algae (zooxanthellae) give coral its colour, so without the algae the coral has no colour and looks white in appearance due to limestone shell. The warmer water also encourages the growth of harmful algae on top of the coral, which kill it.

The direct way in which humans destroy coral reefs is by physically killing them. Fisherman want lots of fish and most of them are not very well skilled at fish catching. Often they blow up a coral reef with explosives and then catch all the stunned fish swimming around. This completely destroys the reefs, killing the coral polyps that make it as well as many of the plants and animals associated with them. Another way in which humans destroy coral reefs is catching coral reef fish by divers using cyanide. The divers pour this poison on the reef, which stuns the fish. Then they rip open the reef with crowbars and catch the fish However, several efforts are being made to save coral reefs. One of them is community care and sustainable resources management. This approach enables to learn and educates people about the management of coral reefs resources. This is facilitated by Coral reef rehabilitation and management program (COREMAP II) as well as the ministry of marine and fishery, trying to convince them to manage their coral reef resources. Government encourage costal community to eliminate bomb and cyanide, catch fish by sustainable fishing gears, and increase their income with alternative income generation activities. They also urge them to enhance their prosperous life with seed fund and village block grant. In several villages in eastern Indonesia, communities help coral reefs by making marine protected areas. The best way that people learn more about managing coral reefs is by protecting coral reef from destroyed activity.

\section{Materials and methods}

My research was situated in 39 stations at Southeast Sulawesi Eastern Indonesia, during July-November 2007 and July-November 2008. All the sampling sites were established as Community Base Marine Protected Areas (MPAs). In order to clarify coral reef condition in all stations, survey and monitoring of coral reef were conducted in 39 stations by free swimming method as preliminary assessment. Line Intercept Transect (LIT) Method (English et al, 1994) was used to observe life form and other benthic component in Marine Protected Areas (MPA) up to $50 \mathrm{~m}$. I chose the transect line because it has proven suitable for quantitative study of hermatypic corals in coral reef. The line was held directly above the substrate. All sessile benthic organism and substrate types were observed using LIT methods. Coral, algae and other benthic organism were identified and grouped in to following categories; live coral, dead coral, algae, other fauna and abiotic substances, according to Veron (1986) and Richmon (1997)

In order to determine fish population in MPAs, Belt Transect Method was conducted during July-November 2007, July-November 2008 and July-November 2009. Fish counts were undertaken by scuba diver, swimming along the $50 \mathrm{~m}$ length measuring line. All target fish were kept within a box The target fish are recorded at family and species level (according to Beger et al. 2003).

\section{Results and Discussion}

By 2006, Coral reef Rehabilitation and Management Program Phase II (Coremap II) supported coastal community to establish marine protected area in several villages in Southeast Sulawesi, Eastern Indonesia. In Eastern Indonesia, community based marine protected areas include more than 250 areas in 250 villages under village regulated reinforcement. These MPAs cover the areas of 4 to $10 \mathrm{Ha}$. 
All the MPAs are distributed in 7 districts. All MPAs arrangement is facilitated by local government and supported by Coremap II. In Philippine, Community-based MPA arrangement is facilitated by government and consists of a no take zone with some type of buffer and other nearby zone within which extractive and non extractive uses are regulated (Cristie and White, 2007). From 2007, local people in this region have started to create marine protected areas using community participation in their village's marine areas. Out of 136 coastal villages, 39 coastal villages have marine protected areas. Around $21 \mathrm{~km}^{2}$ areas of marine protected areas were created from a total coral reef area of $217.93 \mathrm{~km}^{2}$ in Buton Regency. Generally, characteristic of coral reef in this region is coral massive, coral branching, coral encrusting, Acropora, soft coral and sponge (Table 1).

In Philippines, coast covers wide area, including 18.000 sq $\mathrm{km}$ of coral reefs. However, only $5 \%$ of coral reef area remains in excellent condition, and others are in poor or fair condition (Casia, 2000).

Coral reef survey and monitoring in 39 marine protected sites conducted in July-November 2007 showed 30\% of live coral, $40 \%$ of dead coral, $17 \%$ of other fauna, $11 \%$ of abiotic substances (sands and stones), and $2 \%$ of macro algae covered entire coral reef in these regions (Figure 1).

In July-November 2008, the coverage of live coral reef increased to $33.3 \%$, dead coral decreased to $36 \%$, other fauna reached to $6.6 \%$, abiotic substances (sands and stones) turned into $19.5 \%$ and macro algae increased to $4.9 \%$. These figures describe that within 1 year, community involvement through this program has successfully in- creased live coral by $3.14 \%$ of, $4 \%$ decreasing of dead coral, $10.6 \%$ decreasing of other fauna, $9 \%$ increasing of abiotik (sands and stones) and $2.8 \%$ increasing of algae.

Different condition occurred in marine reserved in Papua New Guinea. Coral covering varied during 2006 (3 years after marine reserve establishment) and 2003. There are records of decline in coral cover from 66\% in 1996 to $7 \%$ in 2002 . This condition addressed the increase of turf algae (Geoffrey et al, 2004). The decline in coral cover in MPA was very similar to that in open areas.

In Bahamian marine reserve, the proportional increase (mean of $19 \%$ per site) of coral cover after $2-5$ years was fairly high inside the reserve sites and significantly greater than that in non-reserve sites. The coral cover increased at sites with relatively low macroalgal cover but declined at sites with high cover (Mumby and Harborne, 2010).

During our observation of total 39 MPAs, we found two community base MPAs were in very good condition with $>62 \%$ of living coral. Three MPAs were in good condition with $>40 \%$ of living coral and six MPAs were in fair condition with $>25 \%$ of living coral (Fig. 2). The remaining 28 MPA were in bad conditions with $<20 \%$ of living coral. There are similar conditions of live coral cover in community base MPA at Eastern Indonesia.

In Wakatobi Community Base MPA, live coral covered $30.39 \%$ area (Dhewani et al. 2006). In Pangkep MPA, the live coral cover varied between $0-62.50 \%$ (Manuputty et al. 2007). In Waigeo island, one of the community base MPA in Raja Ampat Irian, live coral covered only 25\% during 2006 (Giyanto et al, 2006). In Selayar Island, the live coral cover varied between 25-49\% (Giyanto, 2006).

Table 1 The name and area of MPA with characteristic coral types

\begin{tabular}{|c|c|c|c|c|c|}
\hline No. & MPA name & Latitude & Longitude & Area (ha) & Characteristics \\
\hline 1 & Wabula \& Wasapela & $05^{\circ} 35^{\prime} 59.7^{\prime \prime}$ & $122^{\circ} 52^{\prime} 33.5^{\prime \prime}$ & 20.00 & $\begin{array}{l}\text { Massive coral, branching coral and soft } \\
\text { coral }\end{array}$ \\
\hline 2 & $\begin{array}{l}\text { Kaombona and } \\
\text { Wasuemba }\end{array}$ & $05^{\circ} 38^{\prime} 25.7^{\prime \prime}$ & $122^{\circ} 50^{\prime} 24.8^{\prime \prime}$ & 10.00 & $\begin{array}{l}\text { Massive coral, branching coral and soft } \\
\text { coral }\end{array}$ \\
\hline 3 & Labara & $05^{\circ} 34^{\prime} 09.6^{\prime \prime}$ & $122^{\circ} 54^{\prime} 28.0^{\prime \prime}$ & 2.50 & $\begin{array}{l}\text { Encrusting coral, branching coral and soft } \\
\text { coral }\end{array}$ \\
\hline 4 & Magarasang & $05^{\circ} 25^{\prime} 18.7^{\prime \prime}$ & $122^{\circ} 18^{\prime} 30.2^{\prime \prime}$ & 15.00 & $\begin{array}{l}\text { Encrusting coral, branching coral and soft } \\
\text { coral }\end{array}$ \\
\hline 5 & Wasitanga & $05^{\circ} 23^{\prime} 28.2^{\prime \prime}$ & $122^{\circ} 16^{\prime} 40.3^{\prime \prime}$ & 1.00 & $\begin{array}{l}\text { Encrusting coral, branching coral and soft } \\
\text { coral }\end{array}$ \\
\hline 6 & Tanjung Weta & $05^{\circ} 22^{\prime} 39.1^{\prime \prime}$ & $122^{\circ} 15^{\prime} 58.1^{\prime \prime}$ & 1.50 & Acropora spp., and massive coral \\
\hline 7 & Tongali & $05^{\circ} 37^{\prime} 44.2^{\prime \prime}$ & $122^{\circ} 31^{\prime} 51.2^{\prime \prime}$ & 2.00 & Acropora spp., and soft coral \\
\hline 8 & Wakinamboro & $05^{\circ} 38^{\prime} 32.1^{\prime \prime}$ & $122^{\circ} 32^{\prime} 28^{\prime \prime}$ & 2.00 & Acropora spp., and soft coral \\
\hline 9 & Wunto & $05^{\circ} 41^{\prime} 18.1^{\prime \prime}$ & $122^{\circ} 32^{\prime} 35.7^{\prime \prime}$ & 2.40 & Branching coral, and massive coral \\
\hline
\end{tabular}


Table 1 (Continued)

\begin{tabular}{|c|c|c|c|c|c|}
\hline No. & MPA name & Latitude & Longitude & Area (ha) & Characteristics \\
\hline 10 & Lapaguruma & $05^{\circ} 39^{\prime} 02.0^{\prime \prime}$ & $122^{\circ} 29^{\prime} 43.3^{\prime \prime}$ & 12.25 & Massive coral \\
\hline 11 & Haukowata & $06^{\circ} 12^{\prime} 20.3^{\prime \prime}$ & $122^{\circ} 43^{\prime} 12.5^{\prime \prime}$ & 1.50 & Massive coral \\
\hline 12 & Haukowalala & $06^{\circ} 12^{\prime} 19.3^{\prime \prime}$ & $122^{\circ} 44^{\prime} 09.9^{\prime \prime}$ & 2.00 & Soft coral and macro algal \\
\hline 13 & Wabide & $06^{\circ} 11^{\prime} 55.0^{\prime \prime}$ & $122^{\circ} 42^{\prime} 25.1^{\prime \prime}$ & 1.50 & Massive coral and soft coral \\
\hline 14 & Nambokondolo & $06^{\circ} 12^{\prime} 47.7^{\prime \prime}$ & $122^{\circ} 41^{\prime} 33.6^{\prime \prime}$ & 0.75 & Soft coral and sponge \\
\hline 15 & Tombuku & $05^{\circ} 29^{\prime} 16.4^{\prime \prime}$ & $122^{\circ} 04^{\prime} 26.9^{\prime \prime}$ & 7.00 & Soft coral and sponge \\
\hline 16 & Tapi-Tapi & $05^{\circ} 30^{\prime} 18.2^{\prime \prime}$ & $122^{\circ} 05^{\prime} 30.5^{\prime \prime}$ & 17.50 & Soft coral and sponge \\
\hline 17 & Lana Buntari & $05^{\circ} 31^{\prime} 14.2^{\prime \prime}$ & $122^{\circ} 04^{\prime} 35.8^{\prime \prime}$ & 5.00 & Soft coral and sponge \\
\hline 18 & Lasurawata & $05^{\circ} 24^{\prime} 21.6^{\prime \prime}$ & $123^{\circ} 07^{\prime} 01.4^{\prime \prime}$ & 4.00 & Hard coral \\
\hline 19 & Waculabara & $05^{\circ} 21^{\prime} 18.3^{\prime \prime}$ & $122^{\circ} 08^{\prime} 40.2^{\prime \prime}$ & 1.50 & Hard coral \\
\hline 20 & Mata Morengka & $05^{\circ} 15^{\prime} 47.6^{\prime \prime}$ & $123^{\circ} 12^{\prime} 10.2^{\prime \prime}$ & 2.00 & Hard coral \\
\hline 21 & Napa & $05^{\circ} 31^{\prime} 19.8^{\prime \prime}$ & $122^{\circ} 28^{\prime} 23.5^{\prime \prime}$ & 1.00 & Branching coral \\
\hline 22 & Liwuto & $05^{\circ} 31^{\prime} 19.5^{\prime \prime}$ & $122^{\circ} 28^{\prime} 22.2^{\prime \prime}$ & 1.00 & Branching coral \\
\hline 23 & Labalsawa & $05^{\circ} 33^{\prime} 10.2^{\prime \prime}$ & $122^{\circ} 30^{\prime} 04.2^{\prime \prime}$ & 5.00 & Branching coral \\
\hline 24 & Lakamboi & $05^{\circ} 34^{\prime} 06.6^{\prime \prime}$ & $122^{\circ} 29^{\prime} 10.6^{\prime \prime}$ & 5.39 & Hard coral \\
\hline 25 & Waburi & $05^{\circ} 21^{\prime} 53.4^{\prime \prime}$ & $122^{\circ} 28^{\prime} 42.3^{\prime \prime}$ & 3.00 & Hard coral \\
\hline 26 & Mawaundu & $05^{\circ} 23^{\prime} 54.2^{\prime \prime}$ & $122^{\circ} 28^{\prime} 05.1^{\prime \prime}$ & 5.00 & Hard coral \\
\hline 27 & Topa & $05^{\circ} 24^{\prime} 05^{\prime \prime}$ & $122^{\circ} 27^{\prime} 16^{\prime \prime}$ & 5.00 & Hard coral \\
\hline 28 & Kabintila & $05^{\circ} 23^{\prime} 43.2^{\prime \prime}$ & $122^{\circ} 18^{\prime} 11.4^{\prime \prime}$ & 3.75 & Hard coral \\
\hline 29 & Wakomba & $05^{\circ} 22^{\prime} 41.3^{\prime \prime}$ & $122^{\circ} 22^{\prime} 25.1^{\prime \prime}$ & 3.00 & Hard coral \\
\hline 30 & Wakomba & $05^{\circ} 20^{\prime} 17.4^{\prime \prime}$ & $122^{\circ} 20^{\prime} 12.3^{\prime \prime}$ & 2.70 & Hard coral \\
\hline 31 & Molona & $05^{\circ} 10^{\prime} 30^{\prime \prime}$ & $122^{\circ} 40^{\prime} 80^{\prime \prime}$ & 5.00 & Hard coral \\
\hline 32 & Satinggi & $06^{\circ} 10^{\prime} 80^{\prime \prime}$ & $122^{0} 45^{\prime} 90^{\prime \prime}$ & 10.00 & Fringing reef \\
\hline 33 & Lalole & $05^{\circ} 40^{\prime} 126.9^{\prime \prime}$ & $122^{\circ} 28^{\prime} 06.9^{\prime \prime}$ & 9.00 & Hard coral and soft coral \\
\hline 34 & Lapalosi & $05^{\circ} 41^{\prime} 19.7^{\prime \prime}$ & $122^{\circ} 43^{\prime} 07.4^{\prime \prime}$ & 6.00 & Hard coral and soft coral \\
\hline 35 & Pingkolua Permai & $05^{\circ} 39^{\prime} 11.1^{\prime \prime}$ & $122^{\circ} 42^{\prime} 49.4^{\prime \prime}$ & 9.00 & Massive coral \\
\hline 36 & Kacimbola & $05^{\circ} 38^{\prime} 40.4^{\prime \prime}$ & $122^{\circ} 45^{\prime} 18.5^{\prime \prime}$ & 3.00 & Hard coral \\
\hline 37 & Wandelapi & $05^{\circ} 41^{\prime} 39.2^{\prime \prime}$ & $122^{\circ} 37^{\prime} 59.8^{\prime \prime}$ & 3.00 & Massive coral and soft coral \\
\hline 38 & Molewa & $05^{\circ} 41^{\prime} 38.4^{\prime \prime}$ & $122^{\circ} 37^{\prime} 59.4^{\prime \prime}$ & 7.00 & Massive coral and soft coral \\
\hline 39 & Dadawi & $05^{\circ} 40^{\prime} 27.4^{\prime \prime}$ & $122^{\circ} 37^{\prime} 15.8^{\prime \prime}$ & 3.00 & Massive coral \\
\hline
\end{tabular}
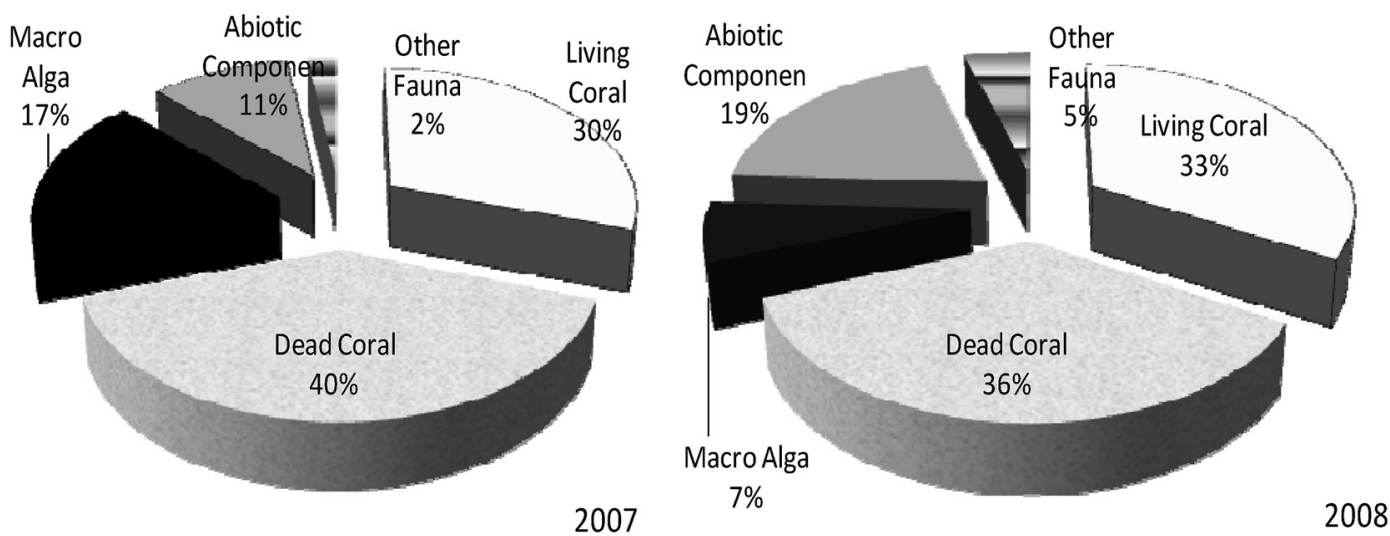

Fig. 1 The average percentage composition of coral reef in sampling sites during 2007 and 2008

Fish population in every MPA increased during JulyNovember 2007, July-November 2008 and July-November 2009. The number of target fish species increased from 52 species in 2007 to 62 species in 2008 and 108 species in 2009. The target fishes are groups of economic fishes which are commonly available in coral reefs and become major target of fishermen (Table 2). The similar trend of population of fish also occurs in the Mimiwhangata Marine Park (New Zealand), In these areas, the snapper (Pagrus auratus), the most heavily targeted fish species, showed no difference in abundance or size between the Marine Park and adjacent control areas (Denny and Babcock, 2004).

Increased fish populations in the waters are not always 


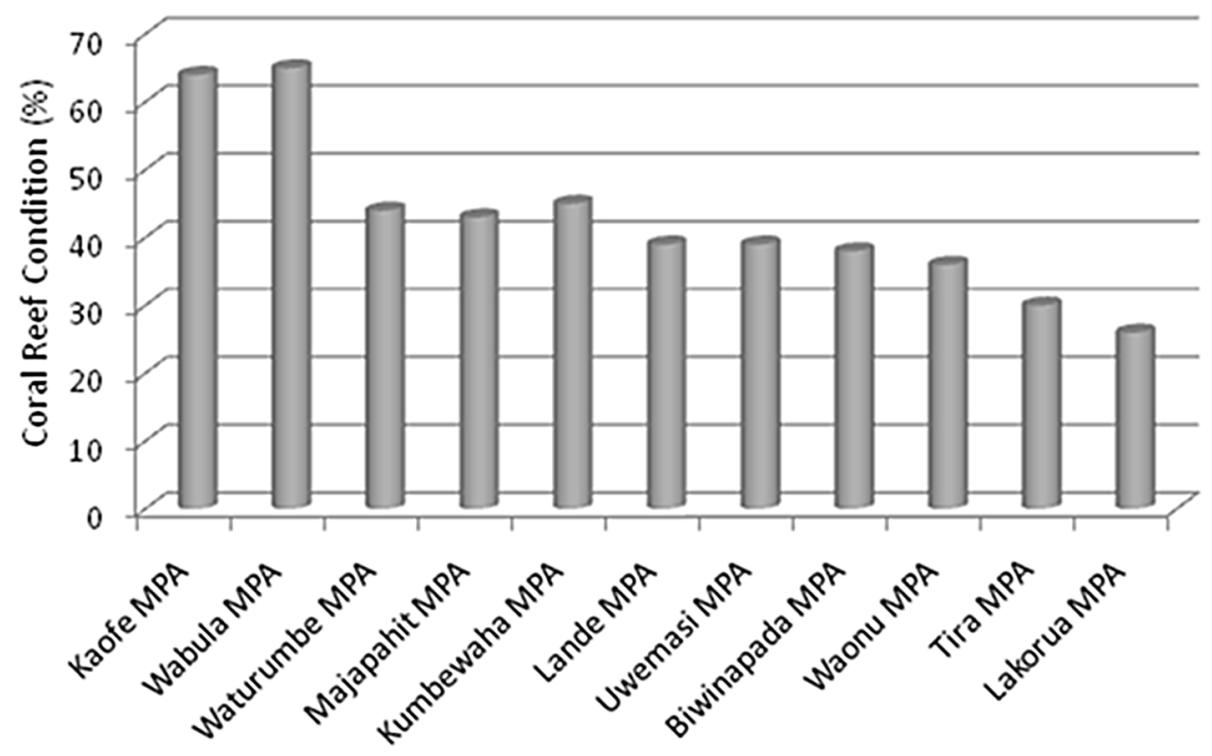

Fig. 2 The percentage of living coral covered for several MPA in sampling sites

addressed by determining the area to be protected areas. Pelletier et al. (2005) estimated that the overall species richness of fish assemblage was not sensitive to MPA status in some areas studied.

Three-year survey using Underwater Visual Censuses (UVC), before and after MPA establishment in a north western Mediterranean marine reserve, showed that abundances and diversity among this area were different. There were significant effects for many of these metrics of fish. The most sensitive metrics were related to large species and species targeted by fishing. There are many evidences which address the effects of MPA on increasing fish size and abundance (see Roberts and Polunin, 1991; Dugan and Davis, 1993; Rowley, 1994; Bohnsack, 1998; Halpern, 2003).

Marine protected areas at the village's level were created through community participation. In order to optimize an understanding and pursuance of marine protected area to the entire people, village regulations were formulated during community workshop conducted in 2007 aimed to support effective implementation of marine protected area. This process was facilitated by Coral Reef Rehabilitation and Management Program phase II (COREMAP II) of Buton regency funded by the World Bank. This facilitation includes socialization, community support through community base management and public awareness.
Table 2 Group of fish in MPA of Buton district during 2007, 2008 and 2009

\begin{tabular}{|c|c|c|c|c|c|c|}
\hline \multirow[b]{2}{*}{ Groups of Fish } & \multicolumn{2}{|c|}{2007} & \multicolumn{2}{|c|}{2008} & \multicolumn{2}{|c|}{2009} \\
\hline & 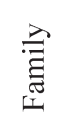 & $\begin{array}{l}\frac{\tilde{D}}{\tilde{D}} \\
\frac{\tilde{D}}{\tilde{n}}\end{array}$ & 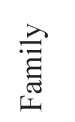 & $\begin{array}{l}\frac{\mathscr{U}}{\tilde{D}} \\
\frac{\mathscr{D}}{\infty}\end{array}$ & 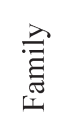 & $\begin{array}{l}\frac{\tilde{\alpha}}{0} \\
\frac{\tilde{D}}{\tilde{N}}\end{array}$ \\
\hline Target & 16 & 52 & 15 & 62 & 19 & 108 \\
\hline Indicator & 1 & 29 & 12 & 66 & 1 & 31 \\
\hline Mayor & 5 & 20 & 1 & 19 & 11 & 49 \\
\hline Amount & 22 & 111 & 28 & 147 & 31 & 188 \\
\hline
\end{tabular}

\section{Conclusions}

Coral Reef condition in Marine Protected Areas of Southeast Sulawesi in Eastern Indonesia showed that live coral increased by $3.14 \%$, dead coral decreased by $4 \%$, other fauna decreased by $10.6 \%$, abiotic substances (sands and stones) increased by $9 \%$ and algae increased by $2.8 \%$. Moreover, most of the coral fishes, particularly those of target fish group (economic fish) increased during 2007, 2008 and 2009.

\section{References}

Beger M, Richards ZT (2007) Finding Napo: Conservation of Napoleon Wrasse and Rare Corals 2006. Report to the bp- 
conservation programme. Melbourne, Australia, pp 1-37

Beger M, Jacobson D, Pinca S, Richards ZT, Hess D, Harriss F,

Page K, Peterson E, Baker N (2008) The State of Coral Reef Ecosystems of the Republic of the Marshall Islands in: The State of Coral Reef Ecosystems of the United States and Pacific Freely Associated States: 2008, Waddell JE and Clarke AM (eds.), NOAA

Beger M, Jones GP, Munday PL, (2003) Conservation of coral reef biodiversity: a comparison of reserve selection procedures for corals and fishes. Biol Conserv 111: 53-62

Beenearts N, Bergh EV, (2005) Comparative Study of Tree Transect Methods to Assess Coral Cover, Richness and Diversity. Western Indian Ocean J. Mar Sci 4: 29-37

Bohnsack JA, (1998) Application of marine reserves to reef fisheries management. Australian J Ecol 23: 298-304

Casia M, (2000) Introduction to the Establishment of a Community base marine Sanctuary, The coastal Resources management Project. Philippine

Claudeta J, Pelletierb D, Jouvenelc JY, Bachetd F, Galzina R (2006) Assessing the effects of marine protected area (MPA) on a reef fish assemblage in a northwestern Mediterranean marine reserve: Identifying community-based indicators, Biol Conserv 130(3): 349-369

Cristie P, White AY (2007) Best Practices for Improved Government of Coral reef marine Protected Area, Coral Reefs, Report, DOI 10-1007/s00338-007-0235-9

Denny CM, Babcock RC (2004) Do partial marine reserves protect reef fish assemblages? Biol Conserv 116: 119-129

Depatemen Kelautan dan Perikanan, Direktorat Jendral Kelautan, Pesisir dan Pulau-Pulau Kecil, (2007) Pedoman Umum Pengelolaan Proyek COREMAP II, Coral Reef Rehabilitation and Management Program Phase II. Jakarta

Dhewani NW, Budiyanto A, Yahmantoro, Effendy A, Picasou J, Dendy A, Salatalahi A, Zulfianita D (2006) Study Baseline Ekologi Kabupaten Wakatobi, CRITC Coremap II LIPI, www.coremap.or.id

Dugan JE, Davis GE (1993) Application of marine refugia to coastal fisheries management. Canadian J Fisheries Aqua Sci 50: 2029-2041

English SA, Wilkinson CR, Baker VJ (eds.) (1997) Survey manual for tropical marine resources. Australian Institute of Marine Science, Townsville

Foale SJ, Manele B, (2004) Social and political barriers to the use of Marine Protected Areas for conservation and fishery management in Melanesia. Asia Pacific Viewpoint in press Giyanto, Hukom F, Ringo RMS, Salatalohi A, Yahmantoro, Haryanto R (2006) Study Baseline Ekology Kabupaten Selayar, CRITC Coremap II LIPI. www.coremap.or.id

Giyanto, Suharti SR, Leatemia WF, Budiyanto A, Salatalohi A, Alik R, Hehuat Y, Razak AD, Hamid, Arafat Y, Latif Y (2006) Study Baseline Ekologi Kabupaten Raja Ampat, CRITC Coremap II LIPI, www.coremap.or.id

Geoffrey PJ, Mark I, McCormick, Srinivasan M, Eagle JV (2004) Coral decline threatens fish biodiversity in marine reserves, www.pnas.orgcgidoi10.1073pnas.04 01277101

Halpern B (2003) The impact of marine reserves: do reserves work and does reserve size matter? Ecol App 13: S117S137

ISRS (2004) Marine Protected Areas (MPAs) in Management of Coral Reefs. Briefing Paper 1, Int Soc Reef Studies, p 13

Leis JM (2002) Pacific coral-reef fishes: the implications of behaviour and ecology of larvae for biodiversity and conservation, and a reassessment of the open population paradigm. Environ Biol Fishes 65: 199-208

Manuputty, Suyarso A, Budiyanto A, Marseno J, Sumadiyo (2007) Study Baseline Ekology Kabupaten Raja Ampat. CRITC Coremap II LIPI, www.coremap.or.id

Mumby PJ, Harborne AR (2010) Marine Reserves Enhance the Recovery of Corals on Caribbean Reefs. PLoS ONE 5(1): e8657. doi:10.1371/journal.pone.0008657

Pelletier D, García-Charton JA, Ferraris J, David G, Thébaud O, Letourneur Y, Claudet J, Amand M, Kulbicki M, Galzin R (2005) Designing indicators for assessing the effects of marine protected areas on coral reef ecosystems: A multidisciplinary standpoint. Aqua Living Resources 18: 15-33

Richmond, M.D. (1997) A guide to the seashores of eastern Africa and the Western Indian Ocean, islands. Sida-SAREC, Sweden, pp 448

Roberts CM, Polunin NVC (1991) Are marine reserves effective in management of reef fisheries? Rev Fish Biol Fisheries 1: 65-91

Rowley RJ (1994) Case studies and reviews - Marine reserves in fisheries management. Aquatic Conservation: Mar Freshw Ecos 4: 233-254

Veron, J.E.N. (1986) Corals of Australia and the Indo-Pacific, Townsville. Australian Institute of Marine Science, pp 644

C Japanese Coral Reef Society 